\title{
Neural tube defect in pregnancy with hyperhomocysteinemia: a case report
}

\author{
Shweta $^{1 *}$, Anuradha Khanna ${ }^{2}$ \\ ${ }^{1}$ Department of Obstetrics \& Gynecology, Mahatma Gandhi Medical College and Research Institute, Pondicherry, \\ India \\ ${ }^{2}$ Department of Obstetrics \& Gynecology, BHU, Varanasi, Uttar Pradesh, India
}

Received: 02 January 2014

Accepted: 02 February 2014

\section{* Correspondence:}

Dr. Shweta Gupta,

E-mail: shwetaguptadr15@gmail.com

(C) 2014 Shweta et al. This is an open-access article distributed under the terms of the Creative Commons Attribution Non-Commercial License, which permits unrestricted non-commercial use, distribution, and reproduction in any medium, provided the original work is properly cited.

\begin{abstract}
The most common cause of elevated homocysteine is the C667T thermolabile mutation of the enzyme 5,10-methylene tetrahydrofolate reductase (MTHFR), inheritance is autosomal recessive. Elevated levels of homocysteine may also result from deficiency of one of several enzymes involved in methionine metabolism and from correctible nutritional deficiencies of folic acid, vitamin $\mathrm{B}_{6}$, or vitamin $\mathrm{B}_{12}$. During normal pregnancy, mean homocysteine plasma concentrations are decreased. Thus, to make a diagnosis in pregnancy, Lockwood (2002) recommends a fasting cutoff level of $>12 \mu \mathrm{mol} / \mathrm{L}$ to define hyperhomocysteinemia. Message: Indians have dietary deficiency of $\mathrm{Vit} \mathrm{B}_{12} \&$ folic acid, as most of us are vegetarians \& habituated of eating cooked vegetables which is one of the reasons for high incidence of hyperhomocysteinemia. So, their diet should be rich in vt $\mathrm{B}_{6}, \mathrm{~B}_{12}$ \& folic acid.
\end{abstract}

Keywords: Homocysteine, MTHFR

\section{INTRODUCTION}

Homocysteine is a thiol (SH) containing amino acid, which is not used in protein synthesis but which is, instead, involved at the junction of two pathways in human physiology.

The most common cause of elevated homocysteine is the C667T thermolabile mutation of the enzyme 5,10methylene tetrahydrofolate reductase (MTHFR), inheritance is autosomal recessive and prevalence of 8 percent in normally pregnant women. Elevated levels of homocysteine may also result from deficiency of one of several enzymes involved in methionine metabolism and from correctible nutritional deficiencies of folic acid, vitamin $\mathrm{B}_{6}$, or vitamin $\mathrm{B}_{12}{ }^{1}$

In the last decade, a close association has been shown between hyperhomocysteinemia and various complications of pregnancy. These include $1^{\text {st }}$ trimester complications like Neural tube defects (NTD), congenital defects like cleft lip, cleft palate and spontaneous abortions. $^{4}$

Hyperhomocysteinemia has also known to be associated with $2^{\text {nd }}$ and $3^{\text {rd }}$ trimester complications like preeclampsia, abruptio-placenta, deep venous thrombosis, intra uterine growth restriction (IUGR) and intra uterine fetal death (IUFD). ${ }^{3,4}$

The association between hyperhomocysteinemia and NTD is the strongest. ${ }^{4}$

\section{CASE REPORT}

A 25 yrs old lady, $\mathrm{G}_{4} \mathrm{P}_{1+2} \mathrm{~L}_{0}$ at 37 wks $+1 \mathrm{~d}$ gestational age reported to labour room with previous two deliveries with neural tube defects (NTD) \& one first trimester abortion. She was thoroughly booked to us throughout this pregnancy. 
She underwent emergency LSCS the same day for thick meconium in early labour with fetal distress. Per operatively two tight loops of cord was present around the baby's neck. She delivered healthy male baby 2990 grams with no co abnormalities.

She had first issue $3 \frac{1}{2}$ yrs back male full term by LSCS in Bihar, baby had spina bifida, died at 1 month of age. $2 \frac{1}{2}$ yrs back she had spontaneous abortion at 10 weeks gestation followed by dilatation and curettage.

She approached to us for the first time in her $3^{\text {rd }}$ pregnancy at $20 \mathrm{wks}+3 \mathrm{~d}$ with USG diagnosed anencephalic fetus.

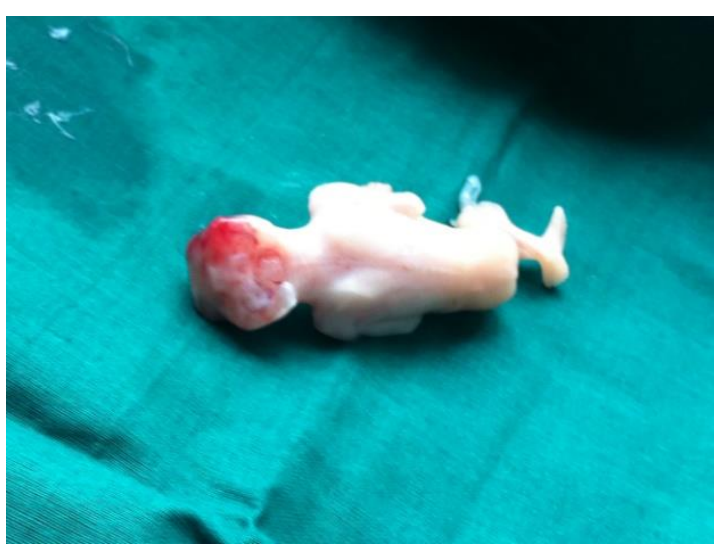

Figure 1: Anencephalic fetus.

Patient was examined and labour was induced following which she expelled 400 gms female anencephalic abortus with spine normal.

Patient was thoroughly investigated in her post-partum period; all routine antenatal investigations came out to be normal. Her blood sugar values fasting and postprandial, VDRL, Toxoplasma and Rubella IgM and IgG were normal.

Later on husband and wife were examined for mutation in MTHR (Methylene tetra hydrofolate reductase) C677T. Husband and wife MTHR both CC with normal report. Wife serum homocysteine level came out to $44 \mu \mathrm{mol} / \mathrm{Lt}$ that is very high level [Normal $10-12 \mu \mathrm{mol} / \mathrm{lt}]$. Husband and wife karyotype were normal.

Since MTHR gene mutation was ruled out, cause of maternal hyperhomocysteinemia assumed to be due to nutritional deficiencies $V$ it $\mathrm{B}_{6}$, Vit $\mathrm{B}_{12}$, folic acid.

Patient was counselled to use contraceptive measures and to increase the dietary intake of folic acid, Vit $\mathrm{B}_{12}$ and Vit
$\mathrm{B}_{6}$. She was given combination of the vitamins in the meantime.

Her homocysteine levels were repeated and came out to be $13 \mu \mathrm{mol} / \mathrm{lt}$.

She came for further follow up at 8 wks $+4 \mathrm{~d}$ gestation and was allowed to continue the pregnancy. Routine antenatal investigations performed. Serial ultrasound scan performed throughout the pregnancy with level II scan done at 20 weeks gestation. She remained in our follow up throughout the pregnancy, thus delivered healthy (M) baby by emergency LSCS for fetal distress.

\section{DISCUSSION}

The reason for high incidence of hyperhomocysteinemia in India include both genetic as well as dietary factors, $1 / 3^{\text {rd }}$ of normal Indian population have deficiency of enzyme MTHFR. Moreover, the Indians have dietary deficiency of $\mathrm{Vit} \mathrm{B}_{12}$, as majority of us are vegetarians and Vit $\mathrm{B}_{12}$ is present mainly in non-vegetarian food. ${ }^{4}$

Indians also have a deficiency of folic acid, as most of us are habituated of eating cooked vegetables, which destroys folic acid.

So combination of all 3 vitamins was given to the patient preconceptionally and was continued till first trimester.

Funding: No funding sources

Conflict of interest: Non declared

Ethical approval: Not required

\section{REFERENCES}

1. F. Gary Cunningham, John C. Hauth, Kenneth J. Leveno, Larry Gilstrap III, Steven L. Bloom, Katharine D. Wenstrom. Thromboembolic disorders. In: Dwight Rouse, Bill Rainey, Cathy Spong, George D. Wendel, eds. Williams Obstetrics. 23rd ed. United States of America: McGraw-Hill Companies, Inc; 2010: 1017

2. Friedman S, Blumberg R S. Inflammatory bowel disease. In: Fauci AS Braunwald EI Sselbacher KJ, et al., eds. Harrison's principles of internal medicine. 16th ed. New York: McGraw Hill Professional; 2005: 2334.

3. Hague WM. Homocysteine and pregnancy. Best Pract Res Clin Obstet Gynaecol. 2003;17(3):459-69.

4. Godbole K, Deshmukh U, Yajnik C. Nutrigenetic determinants of neural tube defects in India. Indian Pediatr. 2009 Jun;46(6):467-75.

DOI: $10.5455 / 2320-1770 . i j r \operatorname{cog} 20140358$

Cite this article as: Shweta, Khanna A. Neural tube defect in pregnancy with

hyperhomocysteinemia: a case report. Int J Reprod Contracept Obstet Gynecol 2014;3:266-7. 